\title{
PARIWISATA SYARIAH DI ACEH TENGAH: PELUANG DAN TANTANGAN STAIN GAJAH PUTIH DALAM PENDIRIAN PRODI PARIWISATA SYARIAH
}

\author{
Joni Harnedi ${ }^{1}$, Yulizar ${ }^{2}$ \\ ${ }^{1,2}$ IAIN Takengon, Aceh Tengah, Indonesia \\ Email: joni_harnedi_ukm@yahoo.ca1 ${ }^{1}$,yulirusydi@gmail.com²
}

\begin{abstract}
This research raises the theme of tourism in Central Aceh as well as the opportunities and challenges of STAIN Gajah Putih in determining the Sharia Tourism Study Program. This research uses a field (field research) with a qualitative approach. Meanwhile, to see the opportunities and challenges of STAIN Gajah Putih in the Islamic tourism study program, this study uses SWOT analysis. As for the opportunities and challenges of STAIN Gajah Putih Takengon in designing the Sharia Tourism study program, it can be seen, first, the strength of the institutional transformation of STAIN Gajah Putih into IAIN, the support of the Regent of Central Aceh in the establishment of the Sharia Tourism Study Program. Second, Weaknesses, the absence of a role model for the Sharia Tourism Study Program and the unavailability of Tourism Lecturer Human Resources at STAIN Gajah Putih. Third, Opportunities, there is no Sharia Tourism Study Program in Aceh province, even in Indonesia there are still 4 universities that have Sharia Tourism Study programs, namely IAIN Batusangkar, IAIN Bukittinggi, College of Economics of Islamic Business Management (STMBI) Al- Aziziyah Randudongkal Pemalang, STAIN Pare-Pare with Islamic Tourism Study Program. Fourth, Threats, global competition, especially tourism, are increasingly selective and rational in choosing educational institutions, and the location of the STAIN Gajah Putih Campus which is far from the city area is a threat to the establishment of a sharia tourism study program and its sustainability.
\end{abstract}

Keywords: Sharia Tourism, Opportunities and Challenges, Sharia Tourism Study Program

\begin{abstract}
Abstrak: Penelitian ini mengangkat tema pariwisata syariah di Aceh Tengah serta peluang dan tantangan STAIN Gajah Putih dalam mendirikan prodi pariwisata syariah. Riset ini merupakan riset lapangan (field research) dengan memakai pendekatan kualitatif. Sedangkan untuk melihat peluang dan tantangan STAIN Gajah Putih dalam perintisan pogram studi pariwisata syariah, maka dalam penelitian ini menggunakan analisa SWOT. Adapun peluang dan tantangan STAIN Gajah Putih Takengon dalam mendirikan program studi pariwisata syariah dapat diketahui, pertama, kekuatan (strengths) adanya transformasi kelembagaan STAIN Gajah Putih menjadi IAIN, adanya dukungan dari Bupati Aceh Tengah dalam pendirian prodi pariwisata syariah. Kedua, kelemahan (Weaknesses), belum adanya role model program studi pariwisata syariah dan belum tersedianya SDM dosen pariwisata di STAIN Gajah Putih. Ketiga, peluang (Opportunities), belum ada program studi pariwisata syariah di provinsi Aceh, bahkan di Indonesia masih 4 perguruan tinggi yang mempunyai program studi pariwisata syariah, yakni IAIN Batusangkar, IAIN Bukittinggi, Sekolah Tinggi Ekonomi Manajemen Bisnis Islam (STMBI) Al-Aziziyah Randudongkal Pemalang, STAIN Pare-Pare dengan prodi pariwisata Islam. Keempat, ancaman (threats), semakin meningkatnya persaingan global khususnya pariwisata syariah, semakin selektif dan rasional dalam masyarakat dalam memilih lembaga pendidikan, dan letak kampus STAIN Gajah Putih yang jauh dari wilayah perkotaan menjadi ancaman serius bagi pendirian program studi pariwisata syariah dan keberlanjutannya.
\end{abstract}

Kata Kunci: Pariwisata Syariah, Peluang dan Tantangan, Prodi Pariwisata Syariah

\section{PENDAHULUAN}

Saat ini, Konsep syariah tidak hanya diminati oleh negara-negara yang berpenduduk muslim saja, tetapi juga sangat diminati oleh negara yang berpenduduk non muslim. Terutama negara yang mengembangkan pariwisata sudah banyak menerapkan wisata syariah atau juga dikenal pariwisata halal. Negera-negara non muslim seperti 
Jepang, Korea dan Eropa berupaya menarik wisatawan muslim dari berbagai negara muslim seperti negara-negara Arab dan Indonesia. Berdasarkan laporan GMT, Indonesia termasuk dalam 10 besar penduduk muslim yang berwisata (Battour et al., 2012; Satriana \& Faridah, 2018).

Provinsi Aceh merupakan daerah yang memiliki potensi besar dalam pengembangan pariwisata syariah. Hampir setiap daerah di provinsi Aceh memiliki potensi wisata yang terus berkembang dan menjadi tujuan destinasi wisata bagi setiap wisatawan lokal maupun mancanegara. Tegaknya syariat Islam di Provinsi Aceh bukanlah menjadi penghalang bagi pengembangan pariwisata di Aceh, bahkan menjadi suatu barometer dalam pengembangan pariwisata syariah di provinsi lainnya di Indonesia.

Salah satu bentuk perhatian terhadap pengembangan pariwisata syariah yang ada di provinsi Aceh yakni dengan kajian yang terus dilakukan dalam upaya pendirian program studi pariwisata syariah. Program studi pariwisata syariah dirancang sebagai salah satu upaya tuntutan masyarakat dan pemerintah daerah untuk membuka program studi yang secara spesifik di bidang pariwisata syariah. Menjawab peluang dan tantangan yang ada di tengah-tengah masyarakat, maka STAIN Gajah Putih Takengon terus berupaya melakukan kajian dan tindak lanjut dalam upaya pendirian program studi pariwisata syariah di STAIN Gajah Putih Takengon.

Pariwisata akan tumbuh serta maju bila dikelola secara maksimal dan kontinu (sustainable). Pengelolaan pariwisata harus menerapkan empat proses, di antaranya; perencanaan, pengorganisasian, pelaksanaan, dan pengawasan. Dalam melakukan pengelolaan pariwisata ini, semua pihak harus bekerja sama, baik pemerintah, masyarakat, pihak swasta, dan perguruan tinggi demi terciptanya keunggulan pariwisata sekarang dan di masa depan (Widiarta, 2016).

Data BPS Kabupaten Aceh Tengah tahun 2017 mengemukakan bahwa Kabupaten Aceh Tengah mempunyai 40 destinasi wisata. Dari sekian banyak destinasi wisata, hanya ada sekitar 25 destinasi wisata yang terdaftar dan berada di Aceh Tengah. Fakta di lapangan ditemukan hal yang berbeda, ada lebih dari 25 destinasi wisata yang berada di sekitar Danau Lut Tawar (Badan Pusat Statistik Aceh Tengah, n.d.; Sutrisno \& Harnedi, 2018). Data yang lain, Kabupaten Aceh Tengah memiliki 62 daya tarik wisata, di mana 40 objek (64\%) adalah wisata alam, 13 objek (21\%) adalah wisata budaya atau peninggalan sejarah dan 9 objek adalah wisata buatan (15\%). Sebagian besar sumberdaya alam, budaya dan buatan tersebut masih berupa potensi. Hanya sekitar 5 objek atau daya tarik wisata yang sudah mempunyai retribusi. Data tersebut di atas menunjukkan bahwa Kabupaten Aceh Tengah mempunyai potensi yang besar dalam pengembangan pariwisata (Kabupaten Aceh Tengah, 2018).

Pembangunan kepariwisataan Kabupaten Aceh Tengah di masa mendatang dihadapkan pada berbagai tantangan dan isu-isu yang tidak mudah untuk dilewati. Perlu pemahaman bersama dan sinergitas antar semua pemangku kepentingan untuk membangun pariwisata Aceh Tengah agar memberikan peningkatan ekonomi bagi masyarakat. Tantangan tersebut antara lain: pemberlakuan syariat Islam, Fakta menunjukkan bahwa masih ada sebagian masyarakat Aceh Tengah yang beranggapan bahwa kegiatan pariwisata identik dengan kegiatan yang lebih banyak mudharat (dampak 
negatif) dibanding manfaatnya. Kondisi ini terjadi karena aktivitas pariwisata masih dipandang kurang sesuai dengan syariat dan wisata memiliki konotasi negatif. Padahal, wisata tidak selalu identik dengan perbuatan melanggar syariat, tergantung bagaimana meramunya ke arah wisata bernuansa syariah dan tidak melanggar adat budaya masyarakat setempat (Kabupaten Aceh Tengah, 2018).

Pemerintah daerah semestinya menggandeng perguruan tinggi dalam mencarikan pemecahan terhadap kompleksitas permasalahan pariwisata di Kabupaten Aceh Tengah. Pengembangan pariwisata di suatu daerah, pemerintah mesti melibatkan pemangku kepentingan seperti pelaku bisnis, komunitas, media terutama akademisi. Dengan kompleksitas kasus pariwisata semacam ini, perguruan tinggi selaku lembaga pembelajaran pariwisata diharapkan sanggup menghasilkan tenaga pakar pariwisata yang mempunyai pola pikir yang orientasinya kesejahtaraan warga. Konsep yang dihasilkan diharapkan mempertahankan orisinalitas sesuatu destinasi wisata dan menjaga kearifan lokal. Penelitian ini bertujuan untuk melihat bagaimana pelaksanaan pariwisata syariah di Aceh Tengah serta sejauh mana peluang dan tantangan STAIN Gajah Putih dalam pendirian Prodi Pariwisata Syariah.

\section{LANDASAN TEORI}

\section{Pariwisata Syariah}

Pariwisata syariah maupun pariwisata halal merupakan 2 istilah yang sering digunakan secara bergantian. Masing-masing negara ataupun daerah menggunakan salah satu dari istilah tersebut. Ada yang menggunakan istilah pariwisata syariah, pariwisata halal ataupun ada juga yang menggunakan parisawata islami. Sementara di Indonesia lebih sering menggunakan pariwisata syariah (sharia tourism) (Djakfar, 2017a; ElGohary, 2016; Henderson, 2010; Satriana \& Faridah, 2018).

Dalam perjalanannya, kehadiran wisata ziarah atau yang dikenal juga dengan wisata religi (pilgrims tourism atau spiritual tourism) merupakan awal dari berkembangnya wisata syariah. Wisata ziarah meliputi kegiatan kunjungan wisata untuk berziarah sesuai dengan ajaran agama seperti Hindu, Budha, Kristen, Islam, serta agama yang lain. Bersamaan dengan itu, kegiatan berwisata tidak hanya berkenaan dengan jenis wisata ziarah atau agama tertentu, tetapi tumbuh menjadi wujud baru nilai-nilai yang bertabiat umum semacam kearifan lokal, berikan khasiat untuk warga, serta faktor pendidikan. Dengan demikian tidaklah perihal yang mustahil bila turis muslim jadi bagian baru yang lagi tumbuh pada bidang pariwisata dunia (Kemenparekraf, 2015).

Dari 5 besar pangsa pasar pariwisata di dunia salah satunya termasuk pariwisata halal. Menurut Thomson Reuters SGIE Report 2017/2018 tahun 2019, jumlah wisatawan muslim mencapai US\$ 169 miliar dengan tingkat pertumbuhan sebesar 6,3\% pertahun jika dibandingkan dengan turis asal Tiongkok pada tahun yang sama sebesar US\$ 179 miliar dengan tingkat pertumbuhan 3,5\% per tahun. Pasar pariwisata halal merupakan Top 3 sumber wisatawan dunia. Tahun 2013 wisatawan muslim mencapai $10 \%$ dari jumlah pasar perjalanan dan mampu meraih pendapatan \$140 Miliar dan diperkirakan pada tahun 2020 meningkat mencapai \$200 Miliar (Wijayanti et al., 2019). 
Pengembangan pariwisata halal sangat cepat terjadi di Indonesia, hal ini dikarenakan mayoritas penduduk Indonesia beragama Islam, sebesar $88 \%$ dari jumlah seluruh penduduk Indonesia dengan memiliki lebih dari 800.000 mesjid. Disamping itu, kebiasaan masyarakat Indonesia yang telah mempunyai pola hidup halal (halal lifestyle) merupakan cikal bakal tumbuh dan berkembangnya wisata halal di Indonesia (Djakfar, 2017b).

Tahun 2019 Global Muslim Travel Index menetapkan Indonesia sebagai negara tujuan wisata halal terbaik dari 130 negara lain dengan perolehan nilai 78 bersama dengan Malaysia menduduki peringkat teratas. Prestasi yang membanggakan ini tentunya berdampak positif dalam pengembangan pariwisata halal di Indonesia. Ini diperoleh setelah beberapa cara dilakukan untuk pengembangan pariwisata. Sehingga penigkatan perkembangan pariwisata tersebut secara bertahap terus bertumbuh tahun demi tahun. Tahun 2015 Indonesia menduduki ranking 6, tahun 2016 meningkat menjadi ranking 4, tahun 2017 naik menjadi ranking 3 dan tahun 2018 menjadi ranking 2. Akhirnya pada tahun 2019 mendapatkan ranking 1 (Sakti, 2019).

Teoman Duman menyatakan bahwa kajian pariwisata dikaitkan dengan agama terutama Islam merupakan kajian yang baru. Beliau mencatat belum banyak yang konsen membicarakan Islam dan pariwisata. Majalah konsen bicara tentang Islam dan pariwisata www.islamictourism.com, sementara lembaga yang sudah konsen bicara tentang Islam dan pariwisata adalah Organisasi Pariwisata Islam Global (GITO) telah memberikan kesempatan kepada akademisi dan praktisi untuk mempresentasikan pandangan tentang Islam dan pariwisata dalam konferensi internasionalnya (Duman, 2011).

Pariwisata halal sangat mengutamakan norma-norma Islam pada setiap kegiatan wisatawan ataupun pada tempat destinasi wisatanya. Dalam pandangan awam wisata syariah lebih dimaknai sebagai wisata religius, yang hanya terfokus pada kunjungan ke tempat ibadah dan makam-makam untuk berziarah. Namun, secara prinsipnya pariwisata syariah tidak hanya demikian. Akan tetapi, mulai dari tata cara perjalanan, kegiatan, dan fasilitas yang tersedia untuk wisatawan. Mulai bandara halal hingga toilet halal di lokasi wisata. Dengan kata lain, pariwisata syariah bermakna bahwa masyarakat atau wisatawan muslim harus berprilaku islami di manapun dan kapanpun. Maka, bila ada pemaknaan yang kurang tepat terkait pariwisata syariah, itu disebabkan karena kurangnya edukasi.

Wisata berbasis syariah diantaranya beberapa kegiatan mengunjugi daerah, kotakota yang memiliki warisan budaya islami, hutan alami, ekowisata lainnya. Di tempattempat tersebut wisatawan bisa berbelanja dan berkeliling kota yang kaya nuansa religi. Salah satu bentuk penerapan nuansa islami yaitu dengan adanya hotel atau penginapan syariah, menyediakan makanan halal, mengizinkan pasangan wisatawan menginap hanya yang memiliki buku nikah, tidak menawarkan minumam beralkohol, memisahkan kolam renang pria dan wanita. Pada bulan Ramadhan, pihak hotel menyediakan makanan khusus untuk sahur dan berbuka puasa. Tidak hanya pada bidang perhotelan, akan tetapi konsep wisata syariah juga diterapkan pada penerbangan, dengan tidak menawarkan alkohol dan makanan yang tidak halal lainnya di sepanjang penerbangan (Jaelani, 2017).

Dengan demikian, wisata berbasis syariah akan memberikan sumbangan pendapatan yang signifikan karena aktifitas ekonomi yang berdasarkan pada prinsipprinsip syariah memegang peranan penting pada sektor perekonomian ini. Indonesia 
bersama India, Cina, Turki dan Malaysia adalah negara-negara pencetus yang telah memulai dan terus mengembangkan wisata berbasis syariah. Tidak hanya negara-negara tersebut, ada banyak negara-negara yang mencoba menarik wisatawan muslim dari seluruh dunia dengan menawarkan fasilitas-fasilitas wisata syariah. Selandia Baru pun ikut bertekad untuk menjadi tujuan wisata berbasis syariah yang berkualitas setara dengan kelima negara tersebut plus dengan negara-negara di Kawasan Timur Tengah (Priyadi, 2016).

Pengembangan pariwisata di dunia ini senantiasa tidak terlepas dari industri kreatif yang memanfaatkan kreativitas, keahlian, dan bakat untuk menghasilkan kesejahteraan dan lapangan pekerjaan dengan menciptakan serta mengeksploitasi energi kreasi ataupun energi cipta orang tersebut. Saat ini, industri kreatif ditatap terus menjadi berarti dalam menunjang majunya perekonomian sebab sebagian besar bergantung pada penciptaan pengetahuan lewat kreativitas. Pariwisata membutuhkan rangkaian proses yang kreatif dalam pengembangannya. Karena itu, industri pariwisata mempunyai ikatan timbal balik dengan industri kreatif. Industri kreatif bisa meningkatkan kemampuan pariwisata syariah pada tiap wilayah (Hasyim, 2019).

Dengan demikian, konsep pariwisata syariah akan (a) meyediakan lapangan kerja dengan adanya pertumbuhan ekonomi inklusif, (b) menyeimbangkan dan mengembangkan komunitas yang hidup, sehingga memiliki ketahanan, dan (c) memperbaiki kehidupan masyarakat pada sektor wisata. Selain dari itu semua, pariwisata syariah mencerminkan (a) pertumbuhan kepariwisataan dan ekonomi, (b) peningkatan ilmu keagamaan para pengunjung, (c) baiknya pengelolaan pemerintahan. Oleh karena itu, wisata syariah adalah salah satu upaya mengentaskan kemiskinan dan pengangguran masyarakat, mengurangi depopulasi dan migrasi, meningkatkan pendapatan dan menyediakan lapangan pekerjaan serta merangsang perbaikan produk-produk dan infrastruktur yang islami dan sesuai dengan syariat (Priyadi, 2016).

\section{Pariwisata Syariah di Aceh}

Potensi berkembangnya pariwisata syariah ke depannya dinilai sangat berpotensi besar. Para pebisnis wisata akan melirik pariwisata syariah, sehingga pariwisata syariah akan terus maju dan berkembang. Pengenalan pasar pariwisata syariah tentunya sangat penting dalam rangka pengembangan pariwisata syariah untuk menarik para pebisnis untuk terjun. Keberagaman destinasi wisata di Indonesia sangat mendukung berkembangnya pariwisata syariah, meskipun masih terfokus pada wisata religi dan destinasi wisata lainnya yang juga didukung dengan fasilitas ibadah (Priyadi, 2016).

Provinsi Aceh merupakan daerah yang menjanjikan dalam pengembangan pariwisata syariah. Provinsi Aceh dengan branding wisatanya Cahaya Aceh (the light of Aceh) telah banyak meraih prestasi dalam pengembangan pariwisata halal, diantaranya adalah menempati posisi ke-5 dari top tujuan wisata halal terbaik versi Indonesia Muslim Travel Index (IMTI) (Ifdhal, 2019; Pariwisata RI, 2019). Sebelumnya Aceh sudah mendapatkan penghargaan di World Halal Tourism Awards 2016 dalam 2 kategori yakni Sultan Iskandar Muda International Airport Banda Aceh sebagai World's Best Airport for Halal Travellers, dan Aceh sebagai World's Best Halal Cultural Destination (Kemkominfo RI, 2016; Prakoso, 2016). Selain dari provinsi Aceh meraih 2 kategori 
penghargaan pada World Halal Tourism Awards 2016 di Abu Dhabi, Indonesia dengan keseluruhan memborong 12 kategori dari 16 kategori yang diperlombakan pada kompetisi wisata halal dunia. Hal ini dikarenakan selain menawarkan sejumlah destinasi wisata yang sangat memperhatikan prinsip syariah, provinsi Aceh juga sudah lama berbenah dalam mengembangkan pariwisata sampai ditingkat masyarakat dengan memperhatikan masyarakat untuk menjalankan kehidupannya sesuai dengan prinsip syariah.

Dalam prakteknya di lapangan upaya pemahaman yang dilakukan oleh pemerintah daerah maupun komunitas sadar wisata tentang wisata syariah dengan semua penerapannya masih belum terlalu dikenal di provinsi Aceh dan Kabupaten/Kota yang ada di Aceh. Dengan ditetapkannya kota Banda Aceh oleh Menteri Pariwisata RI sebagai World Islamic Tourism, menjadikan provinsi Aceh secara keseluruhan sebagai tujuan wisata unggulan islami atau wisata halal di Indonesia bagi dunia. Hingga Pemerintah provinsi Aceh serta segala Kabupaten/Kota mulai melaksanakan penguatan terhadap sumber daya manusia demi memajukan pariwisata, pengembangan budaya serta tradisi, pembenahan prasarana serta fasilitas wisata, pengembangan transportasi wisata, serta tetap melakukan sosialisasi dan pembinaan terhadap masyarakat sadar wisata islami.

Pengembangan destinasi wisata halal yang terdapat di Provinsi Aceh difokuskan pada 3 aspek ialah akses, atraksi, serta amenitas. Perbaikan akses difokuskan pada ketersediaan fasilitas transportasi. Pengembangan atraksi dari apa yang dapat dilihat serta dicoba turis di destinasi. Sebaliknya amenitas merupakan seluruh sarana penunjang yang dapat penuhi kebutuhan serta kemauan turis sepanjang terletak di destinasi (Hasyim, 2019).

\section{METODE PENELITIAN}

Riset ini merupakan riset lapangan (field research) dengan memakai pendekatan kualitatif. Ruang lingkup penelitian ini meliputi semua kebijakan, aturan, dan rekomendasi baik berupa arahan dan bimbingan yang dikeluarkan oleh pimpinan STAIN Gajah Putih Takengon dalam upaya pendirian program studi Pariwisata Syariah dan adanya peran pemerintah daerah memberikan dukungan terbentuknya program studi Pariwisata Syariah di Kabupaten Aceh Tengah.

Adapun sumber informasi dalam riset ini diperoleh bersumber pada sumber informasi primer yakni, Ketua STAIN Gajah Putih Takengon, Dinas Pariwisata Kabupaten Aceh Tengah, Dinas Syariah Islam Kabupaten Aceh Tengah, Majelis Adat Gayo Kabupaten Aceh Tengah, Kepala SMK Negeri 5 Takengon selaku sekolah yang memiliki kejuruan pariwisata dan tokoh masyarakat, pemerhati pariwisata dan stakeholders terkait. Dan, sumber data sekunder berupa literatur, brosur, media koran dan informasi internet dan sumber informasi yang lain yang berhubungan dengan penelitian ini. Untuk melihat peluang dan tantangan STAIN Gajah Putih dalam perintisan pogram studi pariwisata syariah, maka dalam penelitian ini menggunakan analisa SWOT.

\section{HASIL DAN PEMBAHASAN}

Melihat lebih jauh tentang pariwisata yang ada di Kabupaten Aceh Tengah, memang sepenuhnya belum menggunakan istilah pariwisata halal maupun pariwisata 
syariah. Akan tetapi, arah pengembangan pariwisata yang ada di kabupaten Aceh Tengah terus mengarah kepada wisata berbasis syariah. Hal ini sesuai dengan visi dan misi pembangunan kepariwisataan Aceh Tengah sebagaimana tertuang dalam Rancangan Qanun Kabupaten Aceh Tengah tentang Rencana Induk Pembangunan Kepariwisataan Kabupaten Aceh Tengah (RIPPARKAB) (Kabupaten Aceh Tengah, 2018).

"Visi pembangunan kepariwisataan kabupaten adalah terwujudnya kabupaten sebagai destinasi ekowisata syariah berbasis alam dan budaya yang bersumber pada kekuatan setempat dan mampu mendorong pembangunan kabupaten untuk meningkatkan kesejahteraan masyarakat secara utuh dan berkelanjutan".

Bupati Aceh Tengah Shabella Abubakar dalam memberikan kata sambutan dan membuka FGD (Focus Group Discussion) Pengembangan Pariwisata Aceh Tengah dengan Kementerian Pariwisata RI pada tanggal 12 September 2019 menyatakan komitmen pemerintah daerah dalam pengembangan pariwisata di kabupaten Aceh Tengah. Hal ini dibuktikan dengan disahkan Qanun RIPPARKAB Kabupaten Aceh Tengah. Dengan adanya Qanun pariwisata tersebut tentunya pemerintah daerah mempunyai landasan dalam pengembangan pariwisata di kabupaten Aceh Tengah. Namun beliau mengingatkan bahwa pengembangan pariwisata di Aceh Tengah tentunya berdasarkan syariat Islam.

Hal ini diperkuat dengan pernyataan Jumadil Enka (Kadis Pariwisata Kabupaten Aceh Tengah) ketika memberikan kata sambutan FGD Pengembagan Pariwisata Aceh Tengah Tanggal 12 September 2019 yakni:

"Pariwisata di Aceh Tengah masih menjadi program pilihan, maka dinas berupaya menjadikan pariwisata menjadi program unggulan........, Pengembangan pariwisata di aceh tengah mesti memperhatikan pariwisata halal atau pariwisata syariah, dengan ditetapkannya Qanun Pariwisata tentunya secara langsung menjadikan pariwisata menjadi program prioritas Pemerintah Daerah".

Selanjutnya Kadis Pariwisata Aceh Tengah menegaskan bahwa dengan ditetapkan Qanun pariwisata Aceh Tengah tentunya akan merubah arah kebijakan pemerintah daerah dalam pengembangan pariwisata Aceh Tengah. Pengembangan pariwisata yang selama ini merupakan program pilihan, tentunya dengan ditetapkan Qanun pariwisata Aceh Tengah menjadi agenda utama oleh pemerintah Aceh Tengah.

Dalam pembangunan pariwisata di kabupaten Aceh Tengah, pemerintah daerah sangat bertekad untuk meningkatkan jumlah pengunjung dan banyaknya tempat yang dikunjungi, serta lamanya hari kunjungan turis. Pembangunan kepariwisataan memiliki peranan berarti dalam aktivitas perekonomian warga paling utama serta ekspansi peluang kerja dan serta peningkatan citra wilayah. Lokasi zona pariwisata bisa dikenal dengan pertumbuhan banyaknya kunjungan wisata, bertambahnya hotel serta penginapan yang menampung turis. Jumlah kunjungan wisata di provinsi Aceh serta kabupaten Aceh Tengah bisa dilihat dalam informasi berikut ini:

Tabel 1. Kunjungan wisatawan mancanegara ke kab/kota di Aceh dari tahun 2004 s.d 2017

\begin{tabular}{rrrrrc}
\hline & & \multicolumn{4}{c}{ T a h u n } \\
\cline { 3 - 6 } No & Kabupaten/Kota & $\mathbf{2 0 1 4}$ & $\mathbf{2 0 1 5}$ & $\mathbf{2 0 1 6}$ & $\mathbf{2 0 1 7}$ \\
\hline 1 & Kab. Aceh Selatan & 42 & 35 & 150 & 21
\end{tabular}


Jurnal As-Salam Vol. 5 No. 1 Januari - Juni 2021: 76 - 89

Joni Harnedi, Yulizar

\begin{tabular}{llrrrr}
\hline 2 & Kab. Aceh Tenggara & 261 & 1,37 & 1,99 & 4,979 \\
3 & Kab. Aceh timur & 7 & 3 & 1 & 69 \\
4 & Kab. Aceh Tengah & 643 & 920 & 671 & 682 \\
5 & Kab. Aceh barat & 28 & 64 & 28 & 18 \\
6 & Kab. Aceh Besar & 24,76 & 27,21 & 35,88 & 30,380 \\
7 & Kota Subulussalam & 3,94 & 5 & 3 & 11 \\
\hline & Jumlah/Total Provinsi Aceh & $\mathbf{5 0 , 7 2}$ & $\mathbf{5 4 , 5 8}$ & $\mathbf{7 6 , 4 5}$ & $\mathbf{7 5 , 7 5 8}$ \\
\hline
\end{tabular}

Sumber: (Pemprov Aceh, 2019)

Tabel 2: Rekapitulasi data pergerakan kunjungan wisatawan mancanegara ke kab/kota di Aceh dari tahun 2004 s.d 2017

\begin{tabular}{llrrrr}
\hline & & \multicolumn{4}{c}{ T a h u n } \\
\cline { 3 - 6 } No & \multicolumn{1}{c}{ Kabupaten/Kota } & $\mathbf{2 0 1 4}$ & $\mathbf{2 0 1 5}$ & $\mathbf{2 0 1 6}$ & $\mathbf{2 0 1 7}$ \\
\hline 1 & Kab. Aceh Selatan & 15,499 & 20,186 & 15,498 & 20,580 \\
2 & Kab. Aceh Tenggara & 20,634 & 10,191 & 14,696 & 20,865 \\
3 & Kab. Aceh Timur & 1,933 & 975 & 3,968 & 14,418 \\
4 & Kab. Aceh Tengah & 33,891 & 35,325 & 36,249 & 38,669 \\
5 & Kab. Aceh Barat & 30,881 & 41,218 & 40,857 & 37,849 \\
6 & Kab. Aceh Besar & 183,441 & 41,348 & 466,742 & 574,079 \\
\hline & Jumlah/Total Provinsi Aceh & $\mathbf{1 , 3 7 7 , 5 4 1}$ & $\mathbf{1 , 6 6 2 , 5 2 8}$ & $\mathbf{2 , 0 7 7 , 7 9 7}$ & $\mathbf{2 , 2 8 8 , 6 2 5}$
\end{tabular}

Sumber: (Pemprov Aceh, 2019)

Data tersebut di atas menunjukkan pergerakan wisatawan yang berkunjung ke kabupaten Aceh Tengah baik itu wisatawan asing maupun wisatawan lokal. Wisatawan Asing yang berkunjung ke kabupaten Aceh Tengah pada tahun 2014 dengan jumlah wisatan sebanyak 643, tahun 2015 sebanyak 920, tahun 2016 sebanyak 671, sementara tahun 2017 sebanyak 682 wisatawan. Adapun wisatawan Nusantara yang berkunjung ke kabupaten Aceh Tengah pada tahun 2017 sebanyak 38,669, mengalami peningkatan dari tahun 2016 yang hanya 36,249 kunjungan wisatawan nusantara. Wisatawan asing yang berkunjung ke Aceh Tengah tahun 2017 meningkat dari tahun 2016, namun dibandingkan dengan tahun 2015 mengalami penurunan sangat drastis. Sementara itu, adanya peningkatan wisatawan nusantara dari tahun-ketahun, dapat dilihat dari data di atas. Bahkan tahun 2018 terjadi peningkatan yang sangat signifikan $129.986(236,15 \%)$ berbanding terbalik dengan wisatawan asing yang hanya 400 turun sebanyak 41,34 \% (Fahlevi, 2019; Tengah, 2018).

Pengembangan wisata syariah di kabupaten Aceh Tengah masih sangat minim keberadaannya. Pemerintah daerah saat ini sedang melakukan pengembangan terhadap destinasi pariwisata yang ada di kabupaten Aceh Tengah agar terus sesuai dengan prinsip dan konsep pariwisata syariah yang ada saat ini. Hal yang dikedepankan dalam upaya branding pariwisata yang ada di kabupaten Aceh Tengah adalah dengan melakukan pengembangan obyek tujuan wisatawan yang tidak hanya semata wisata religi, akan tetapi lebih dari itu yakni melakukan standarisasi tempat-tempat wisata dan juga seluruh kebutuhan wisatawan harus sesuai dengan kaidah Islam.

Selain itu patut menjadi perhatian dalam pengembangan pariwisata di Aceh Tengah mesti memperhatikan kearifan lokal, yakni budaya Gayo (Kamal, 2019; Umar, 2019). Karena Budaya Gayo sangat erat kaitannya dengan agama. Dalam budaya Gayo dikenal 
dengan istilah syarak bersendikan adat yang bermaksud kekuatan dan kekokohan adatistiadat ada pada syarak. Hukum adat sebagai pendukung hukum syarak, dengan kata lain hukum adat sebagai perwujudan berjalannya hukum syarak dalam kehidupan masyarakat (Sukiman, 2014). Wawancara dengan Ketua MPU Kabupaten Aceh Tengah pada 11 September 2019 dan Kepala Dinas Syariat Islam pada 09 September 2019 beliau sangat menekankan bahwa pariwisata yang akan dikembangkan di Aceh Tengah mesti berdasarkan syariat Islam dan budaya Gayo (Kamal, 2019; Umar, 2019). Wisatawan yang berkunjung ke Aceh Tengah mesti memahami dan menyesuaikan dengan agama dan budaya yang berlaku di Gayo. Bahkan ditekankan Ketua MPU Aceh Tengah bahwa jangan sampai masyarakat Gayo yang terpengaruh oleh budaya yang dibawah oleh wisatawan tersebut.

Hal menarik yang ditemukan di lapangan adalah sebagaimana yang dikemukakan oleh Cut Dewi Karmila manager Hotel Bayu Hill pada saat wawancara pada tanggal 2 Oktober 2019 adalah ada beberapa tamu hotel dari wisatawan asing yang sudah menyiapkan selendang ketika berkunjung ke Aceh Tengah, mungkin mereka sudah memahami budaya yang berlaku di tempat yang akan mereka kunjungi.

\section{Analisis SWOT Berdasarkan Kondisi Internal dan Eksternal Pendirian Program Studi Pariwisata Syariah STAIN Gajah Putih Takengon.}

Kekuatan (Strengths): saat ini STAIN Gajah Putih Takengon sedang transformasi status STAIN menjadi IAIN Takengon. Pengajuan perubahan alih status ini telah berjalan lebih dari tiga tahun. Dengan adanya visitasi dari bagian Kementerian Sekretaris Negara dan Kementerian Keuangan serta Bagian Organisasi dan Tata Kelola Kementerian Agama pada 15-18 Oktober 2019 semakin mendekatkan keseriusan pemerintah untuk merubah status STAIN Gajah Putih Takengon menjadi IAIN Takengon. Selain adanya penguatan dalam perubahan status, peran dari pemerintah daerah terutama bupati kabupaten Aceh Tengah dalam mendukung dan memfasilitasi studi kelayakan pendirian program studi Pariwisata Syariah di STAIN Gajah Putih Takengon. Karena adanya dukungan dari segi kelembagaan dan juga pemerintah daerah untuk mendirikan program studi Pariwisata Syariah, tentunya upaya pendirian ini juga didukung oleh besarnya potensi pariwisata yang ada di kabupaten Aceh Tengah sebagai salah satu tujuan wisata syariah yang memiliki potensi daerah yang tinggi, di antaranya wisata religi, budaya, alam, kuliner dan wisata khusus yang ada di kabupaten Aceh Tengah. Keseluruhan wisata yang ada di kabupaten Aceh Tengah sangat didukung dengan kondisi masyarakat yang ramah dan terbuka serta menerapakan prinsip-prinsip syariat Islam dalam kehidupan sehari-hari. Keseluruhan proses pendirian program studi Pariwisata Syariah sesuai dengan Rencana Induk Pengembangan Pariwisata Daerah Kabupaten Aceh Tengah (RIPARDA Kab. Aceh Tengah).

Kelemahan (Weaknesses): dalam perancangan pendirian program studi Pariwisata Syariah di STAIN Gajah Putih Takengon, ada beberapa faktor yang mempengaruhi kelemahan dari perancangan program studi ini. Pertama, belum adanya role model program studi Pariwisata Syariah di Provinsi Aceh maupun perguruan tinggi yang secara spesifik mengelola program studi pariwisata syariah di seluruh kabupaten/kota di Aceh. Tentunya hal ini menjadi kendala dimana belum adanya role model yang dapat menjadi 
acuan bagi pendirian program studi Pariwisata Syariah di STAIN Gajah Putih Takengon. Selama ini peneliti melakukan lebih banyak kajian dan analisis dalam pembukaan program studi pariwisata Syariah mengacu kepada Jurusan Pariwisata Syariah di IAIN Batusangkar. Kedua, ketidaktersediaan SDM juga menjadi pemicu dalam pendirian program studi ini, mengingat STAIN Gajah Putih Takengon belum memiliki dosen yang secara keilmuan dibidangnya. Ketiga, berkaitan dengan pengelolaan pariwisata yang belum maksimal di kabupaten Aceh Tengah, hal ini berimbas kepada penciptaan SDM dan juga penciptaan lokasi wisata baru yang dapat dijadikan sebagai kajian dan fokus pengembangan program studi Pariwisata Syariah. Keempat, belum maksimalnya kerjasama antar perguruan tinggi terutama dalam rumpun keilmuan pariwisata maupun pariwisata syariah. Hal ini akan memicu kepada upaya pengutan dan jalinan kerjasama yang akan mendukung pengelolaan dan pendirian program studi baru di STAIN Gajah Putih Takengon. Kelima, masih tarik ulur antara pemerintah daerah dan STAIN Gajah Putih dalam melakukan kerjasama dan pengembangan pariwisata daerah dan pendirian program studi Pariwisata Syariah.

Peluang (Opportunities): dalam upaya pendirian program studi Pariwisata Syariah di STAIN Gajah Putih Takengon, terdapat beberapa peluang yang ditemukan sebagai daya dukung untuk menunjang keberadaan program studi yang akan diajukan, yakni: pertama, belum adanya program studi Pariwisata Syariah di provinsi Aceh, bahkan di Indonesia masih empat perguruan tinggi yang mempunyai program Studi Pariwisata Syariah, yakni IAIN Batusangkar, IAIN Bukittinggi, STMBI Al-Aziziyah Randudongkal Pemalang, STAIN Pare-Pare dengan Prodi Pariwisata Islam. Kedua, Indonesia sebagai negara pemeluk agama Islam terbesar di dunia yang memiliki beragam objek wisata alam bernuansa syariah seperti situs-situs peninggalan kerajaan Islam dan pusat pesantren Islam. Ketiga, semakin tingginya kesadaran masyarakat akan penggunaan produk halal, ditandai dengan semakin meningkatnya permintaan sertifikasi halal ke badan LPPOM MUI, ini menunjukkan industri halal semakin berkembang. Keempat, prospek pengembangan pariwisata syariah di provinsi Aceh, maupun Aceh Tengah bahkan Indonesia sangat potensial. Berdasarkan pertimbangan ini STAIN Gajah Putih memiliki peluang yang besar mendapatkan mahasiswa untuk program studi pariwisata syariah, serta lulusannya tidak kesulitan untuk diterima pada instansi pemerintah dan industri wisata syariah. Kemudian, dengan adanya semangat transformasi kelembagaan di STAIN Gajah Putih Takengon, akan semakin menambah jumlah program studi dalam menunjang keberadaan IAIN Takengon nantinya. Adanya peran pimpinan STAIN Gajah Putih, Bupati Aceh Tengah, pegiat pariwisata, stakeholders terkait dan seluruh masyarakat yang mendukung berdirinya program studi pariwisata syariah STAIN Gajah Putih Takengon.

Ancaman (Threats): pendirian program studi pariwisata syariah STAIN Gajah Putih Takengon juga harus melihat perkembangan dan kondisi kekinian pariwisata yang ada di daerah, nasional dan juga internasional. Besarnya peluang yang dihadirkan dari sebuah lokasi wisata juga mengakibatkan ancaman yang serius dari dampak lokasi wisata tersebut. Untuk itulah, seluruh ancaman yang ada pada upaya pendirian program studi pariwisata syariah harus segera diminalisir, mengingat kekuatan dan peluang yang dimiliki oleh STAIN Gajah Putih Takengon dan juga potensi wisata yang ada. Adapun ancaman yang ditemukan di lapangan terkait dengan pengajuan program studi pariwisata 
syariah adalah sebagai berikut: pertama, ketatnya persaingan global yang terus menerus kepada upaya perbaikan pelayanan dan juga mutu lulusan dalam menghadirkan program studi baru. Ditambah dengan pengembangan pariwisata harus mengedepankan pada prinsip kekinian dan berbeda dari tempat yang lainnya. Kedua, semakin selektifnya masyarakat dalam memilih lembaga pendidikan yang memiliki prospek kedepannya, apalagi program studi pariwisata syariah memproyeksikan pengembangan lulusan hanya berkisar pada tingkat lokal dan regional. Ketiga, semakin menjamurnya program studi pariwisata yang berlabel syariah maupun Islam, sehingga menyebabkan persaingan dalam mencari pasar dan juga mahasiswa. Keempat, letak geografis STAIN Gajah Putih yang sudah di tengah kota, akan tetapi karena ada pengembangan kampus, pemindahan kampus sejauh $23 \mathrm{KM}$ dari kota menyebabkan ancaman tersendiri bagi para mahasiswa karena letaknya yang agak jauh dan terkesan pelosok.

\section{Analisis Strategi Dalam Mengatasi Kondisi Internal dan Eksternal Pendirian Program Studi Pariwisata Syariah STAIN Gajah Putih Takengon}

Kekuatan (Strengths): strategi yang harus dihadirkan dalam mengoptimalkan kekuatan dalam pendirian program studi pariwisata syariah STAIN Gajah Putih Takengon adalah sebagai berikut: pertama, mengoptimalkan proses tranformasi STAIN menjadi IAIN Takengon dengan cara melengkapi seluruh kebutuhan dan proses dalam upaya percepatan alih status STAIN ke IAIN Takengon. Kedua, menindaklanjuti dukungan dari Bupati Aceh Tengah terhadap pendirian prodi pariwisata syariah. Ketiga, mengembangkan kerjasama dengan pihak-pihak yang berkaitan dengan pariwisata syariah di Aceh Tengah, maupun provinsi Aceh, dalam hal ini Dinas Pariwisata, MPU, Dinas Syariat Islam. Keempat, menyiapkan tim perumusan dan pengajuan proposal pendirian prodi pariwisata syariah.

Kelemahan (Weaknesses): upaya strategi yang dilakukan dalam upaya meminimalisir kelemahan yang terdapat dalam pendirian program studi Pariwisata Syariah STAIN Gajah Putih Takengon adalah sebagai berikut: pertama, mengembangkan Prodi Pariwisata Syariah yang mengakomodir kearifan lokal sebagai role model Prodi Pariwisata Syariah Yang akan didirikan. Kedua, melakukan kerjasama dengan perguruan tinggi yang telah mempunyai program studi pariwisata syariah. Ketiga, kerjasama dengan pemerintah daerah dalam pengembangan pariwisata syariah di daerah maupun dalam pendirian program studi pariwisata syariah.

Peluang (Opportunities): strategi peningkatan yang terdapat dalam peluang pendirian program studi pariwisata syariah adalah sebagai berikut: pertama, meningkatkan kualitas SDM sehingga dapat bersaing dalam dunia global. Kedua, meingkatkan promosi dan sosialisasi STAIN kepada masyarakat. Ketiga, STAIN Gajah Putih segera mengambil peluang pendirian prodi pariwisata syariah dengan besarnya peluang yang ada di tingkat pusat dan kepedulian pemerintah daerah dalam pendirian program studi pariwisata syariah yang tentunya akan berimbas pada perbaikan dan pengembangan pariwisata di kabupaten Aceh Tengah.

Ancaman (Threats): strategi yang digunakan dalam meminimalisir ancaman yang hadir dalam rangka pendirian program studi pariwisata syariah adalah sebagai berikut: pertama, tetap memperhatikan dan mempertahankan karakteristik keaslian dan keunikan 
Aceh dan Aceh Tengah dengan budaya Gayo yang sangat kuat dengan ajaran Islam. Kedua, membedakan program studi pariwisata syariah STAIN Gajah Putih Takengon dengan program studi lainnya dengan cara memiliki ciri khas keilmuan maupun fokus kajian pengembangan pariwisata syariah STAIN Gajah Putih Takengon. Ketiga, harus ada upaya pimpinan dan pemerintah daerah dalam mengupayakan kampus yang strategis dan mudah dijangkau oleh mahasiswa dan juga wisatawan. Hal ini akan mempermudah pengembangan pariwisata dan peningkatan kunjungan serta perbaikan destinasi wisata yang berorientasi pada pelayanan yang prima bagi para mahasiswa dan pengunjung wisata di kabupaten Aceh Tengah.

\section{KESIMPULAN}

Kabupaten Aceh Tengah sebagai salah satu daerah tujuan wisata (DTW) di provinsi Aceh menjadi salah satu magnet bagi seluruh wisatawan yang ingin berkunjung ke "negeri di atas langit". Wisata yang lebih mengedepankan prinsip alamiah dan ekowisata menjadi daya tarik tersendiri bagi kabupaten Aceh Tengah. Dalam upaya memajukan pariwisata di kabupaten Aceh Tengah, tentunya harus diperhatikan ketersediaan penunjang wisata yang baik dan sesuai dengan syariah. Karena wisatawan akan merasa senang dan ingin kembali lagi apabila kunjungannya memberikan kesan dan terfasilitasi dengan baik. Untuk itu semua, salah satu hal yang harus diperhatikan adalah penguatan mutu SDM yang mampu mengelola lokasi wisata yang baik dan sesuai syariah. Untuk menunjang itu semua, maka diperlukan suatu lembaga atau perguruan tinggi yang menghasilkan lulusan yang baik dibidang pariwisata, utamanya pariwisata syariah.

Penelitian ini selanjutnya mengelaborasi lebih jauh tentang peluang dan tantangan pendirian program studi Pariwisata Syariah di STAIN Gajah Putih Takengon. Adapun temuan yang peneliti dapatkan terkait dengan penelitian ini adalah: Kekuatan: transformasi kelembagaan STAIN Gajah Putih Menjadi IAIN Takengon sangat memungkinkan pendirian prodi pariwisata syariah, selain dukungan dari Ketua STAIN Gajah Putih Takengon dukungan juga didapatkan dari Bupati Aceh Tengah. Kelemahan: belum adanya role model program studi pariwisata syariah, belum adanya dosen yang spesifik lulusan pariwisata syariah. Peluang: belum adanya program studi pariwisata syariah di provinsi Aceh, bahkan di Indonesia masih 4 perguruan tinggi yang mempunyai program studi pariwisata syariah, yakni IAIN Batusangkar, IAIN Bukittinggi, STMBI AlAziziyah Randudongkal Pemalang, STAIN Pare-Pare dengan prodi pariwisata Islam. Tantangan: ketatnya persaingan global, masyarakat semakin selektif dan rasional dalam memilih lembaga pendidikan, dan letak kampus STAIN Gajah Putih yang jauh dari wilayah perkotaan menjadi ancaman serius bagi pendirian program studi pariwisata syariah dan keberlanjutannya.

\section{DAFTAR PUSTAKA}

Badan Pusat Statistik Aceh Tengah. (n.d.). Kabupaten Aceh Tengah Dalam Angka 2017. https://acehtengahkab.bps.go.id/publication/2017/08/19/186bd1391fbd2c0964470a ec/kabupaten-aceh-tengah-dalam-angka-2017.html

Battour, M. M., Battor, M. M., \& Ismail, M. (2012). The Mediating Role of Tourist Satisfaction: A Study of Muslim Tourists in Malaysia. Journal of Travel and 
Tourism Marketing, 29(3), 279-297.

https://doi.org/10.1080/10548408.2012.666174

Djakfar, M. (2017a). Pariwisata Halal Perspektif Multidimensi. Malang: UIN Maliki Press.

http://www.uinmalikipress.com

Djakfar, M. (2017b). Pariwisata Halal Perspektif Multidimensi (Peta Jalan Menuju Pengembangan Akademik \& Industri Halal di Indonesia. Malang: UIN Maliki Malang.

Duman, T. (2011). Value of Islamic tourism offering: Perspectives from the Turkish experience. World Islamic Tourism Forum (WITF, 2011), Kuala Lumpur, 12-13 July 2011, 1-9.

http://www.iais.org.my/e/attach/ppts/12-13JUL2011-WITF/abstracts/abstracts.pdf

El-Gohary, H. (2016). Halal tourism, is it really Halal?. Tourism Management Perspectives, 19(December 2015), 124-130.

https://doi.org/10.1016/j.tmp.2015.12.013

Enka, J. (2019). Sambutan Kadisparpora Kabupaten Aceh Tengah dalam FGD Pengembangan Pariwisata Aceh Tengah. Takengon: FGD Pengembangan Pariwisata Aceh Tengah.

Fahlevi, R. (2019). FGD Pengembangan Pariwisata Kabupaten Aceh Tengah. Takengon: FGD Pengembangan Pariwisata Aceh Tengah.

Hasyim. (2019). Masyarakat Ingin Pariwisata Islami. Jakarta: Serambinews.com. https://aceh.tribunnews.com/2019/09/10/masyarakat-ingin-pariwisata-islami.

Henderson, J. C. (2010). Sharia-Compliant Hotels. Tourism and Hospitality Research, $10(3), 246-254$. https://doi.org/10.1057/thr.2010.3

Jaelani, A. (2017). Industri Wisata Halal di Indonesia: Potenssi dan Prospek (Halal Tourism Industry in indonesia: Potential and Prospects). Munich Personal RePEc Archive Halal, 76237, 1-20.

https://mpra.ub.uni-muenchen.de/76237/

Kabupaten Aceh Tengah. (2018). Rencana Induk Pembangunan Pariwisata Kabupaten (RIPPARKAB) Aceh Tengah Tahun 2018-2025. In Dinas Pariwisata Kepemudaan dan Olah Raga Pemerintah Kabupaten Aceh Tengah. Takengon: Dispora Aceh Tengah.

https://doi.org/10.22201/fq.18708404e.2004.3.66178

Kamal, M. (2019). Wawancara Dengan Kepala Dinas Syariat Islam Kabupaten Aceh Tengah. Takengon: Interview.

Kemenparekraf. (2015). Laporan Akhir Kajian Pengembangan Wisata Syariah. Asdep Litbang Kebijakan Kepariwisataan, Syariah Tourism, 1-201.

http://www.kemenpar.go.id/userfiles/2015 Kajian Pengembangan Wisata Syariah.pdf

Kemkominfo RI. (2016). Menangkan WHTA (World Halal Tourism Award) untuk Pariwisata Indonesia di Mata Dunia. Jakarta: Kemkominfo RI.

https://kominfo.go.id/content/detail/8385/menangkan-whta-world-halal-tourismaward-untuk-pariwisata-indonesia-di-mata-dunia/0/artikel_gpr

M. Ifdhal. (2019). Aceh Menuju Destinasi Wisata Halal terbaik. Jakarta: Antara News. https://www.antaranews.com/berita/789697/aceh-menuju-destinasi-wisata-halalterbaik

Pariwisata RI. (2019). 5 Tahun Kembangkan Pariwisata Halal Indonesia Akhirnya Raih Peringkat Pertama Wisata Halal Dunia 2019. Jakarta: Kementerian Parwisata. 
http://mirror.acehprov.go.id/news/read/2019/04/15/6331/5-tahun-kembangkanpariwisata-halal-indonesia-akhirnya-raih-peringkat-pertama-wisata-halal-dunia2019.html

Pemprov Aceh. (2019). Kunjungan Wisatawan_2004sd 2018. Aceh: Pemprov Aceh. https://ppid.acehprov.go.id/assets/uploads/31E1/informasipublik/jbbL/Kunjungan_Wisatawan_2004_s_d_2018.pdf

Prakoso, J. R. (2016). Alhamdulillah, Indonesia Menang 12 Penghargaan World Halal Tourism Awards 2016!. Jakarta: Detik.com. https://travel.detik.com/travel-news/d-3365829/alhamdulillah-indonesia-menang12-penghargaan-world-halal-tourism-awards-2016

Priyadi, U. (2016). Pariwisata Syariah, Prospek dan Perkembangan. Yogyakarta: Sekolah Tinggi Ilmu Manajemen YKPN.

Sakti, G. (2019). Siaran Pers: Indonesia Ditetapkan Sebagai Destinasi Wisata Halal Terbaik Dunia 2019. Jakarta: Kementerian Pariwisata. https://www.kemenparekraf.go.id/post/siaran-pers-indonesia-ditetapkan-sebagaidestinasi-wisata-halal-terbaik-dunia-2019

Satriana, E. D., \& Faridah, H. D. (2018). Halal Tourism: Development, Chance and Challenge. Journal of Halal Product and Research, 1(2), 32. https://doi.org/10.20473/jhpr.vol.1-issue.2.32-43

Shabella, A. (2019). FGD Pengembangan Pariwisata Aceh Tengah. Takengon: FGD Pengembangan Pariwisata Aceh Tengah.

Sukiman. (2014). Nilai-Nilai Pembangunan Islam. Miqot, XXXVIII(1), 215-237. http://jurnalmiqotojs.uinsu.ac.id/index.php/jurnalmiqot/article/view/98

Sutrisno, S., \& Harnedi, J. (2018). Membangun Masyarakat Sadar Wisata dan Sadar Bencana di Kawasan Danau Lut Tawar Takengon. Jurnal As-Salam, 2(3), 93-102. https://doi.org/10.37249/as-salam.v2i3.104

Tengah, B. K. A. (2018). Kabupaten Aceh Tengah Dalam Angka Tahun 2018. Takengon: BPS Aceh Tengah.

Umar, T. H. I. (2019). Wawancara dengan Ketua Majelis Permusyawaratan Ulama (MPU) Kabupaten Aceh Tengah. Takengon: MPU Kabupaten Aceh Tengah.

Widiarta, I. N. (2016). Pengelolaan Daya Tarik Wisata Pura Taman Ayun Sebagai Bagian Dari Warisan Budaya Dunia. Jurnal Master Pariwisata (JUMPA), 2(2), 124-142. https://doi.org/10.24843/jumpa.2016.v02.i02.p08

Wijayanti, A., Widyaningsih, H., Faturrahman Hakim, M., \& Arif Fiyan, M. (2019). Past, Present, and Future Perspectives on The Concept of Halal Tourism. 3rd International Seminar on Tourism (ISOT 2018) Past, 259(Isot 2018), 30-36. https://doi.org/10.2991/isot-18.2019.7 